\title{
Ideologi Kesetaraan Dan Kebebasan Perempuan Dalam Novel Al-Hubb Fii Zamani Nafti
}

\author{
Puji Lestari1*, Mawardi² \\ 1*,2UIN Sunan Gunung Djati Bandung; 1*pujiles98@gmail.com, 2mawardiyahya@gmail.com
}

*Penulis Korespondensi

Artikel Dikirim: 4 September 2020;

Artikel Diterima: 25 Oktober 2020;

Artikel Dipubikasikan: 16 Desember 2020

\begin{abstract}
Abstrak: Penelitian ini membahas tentang ideologi kesetaraan dan kebebasan perempuan menggunakan analisis kritik sastra feminis. Ideologi kesetaraan dalam feminis berkaitan dengan kesetaraan gender bahwa laki-laki dan perempuan mempunyai peran yang sama dalam hal apapun, termasuk dalam hal pekerjaan dan kebudayaannya. Kemudian kebebasan perempuan dalam feminis disebut dengan kebebasan seorang perempuan untuk melakukan hal-hal kearah yang positif, seperti melakukan kebebasan terhadap pekerjaan. Adapun tujuan penelitian ini untuk mengetahui ideologi kesetaraan dan kebebasan perempuan dalam novel Al-hubb fii zamani nafti. Metode penelitian ini menggunakan metode deskriptif kualitatif yang mendeskripsikan data dengan jelas. Sumber data berupa novel Al-hubb fii zamani nafti. Teknik pengumpulan data menggunakan teknik studi pustaka dengan cara membaca, memahami, mencari, dan menandai data. Hasil penelitian yang terdapat dalam novel Al-hubb fii zamani nafti adalah mendeskripsikan ideologi kesetaraan terhadap manusia, alat, budaya. Dan mendeskripsikan kebebasan perempuan terhadap pekerjaannya sebagai pemahat patung yang pada umumnya pekerjaan tersebut dilakukan oleh laki-laki.
\end{abstract}

Kata Kunci: Kesetaraan, Kebebasan Perempuan, Posmodernisme.

Abstract : The research discusses Ideology of Equality and Women's Freedom using Feminist Literary Criticism analysis. The ideology of equality in feminism in related to gender equality in that men and women have the same role in any matter, including in terms of work and culture. Then Women's Freedom in feminism is called the freedom of a woman to do things in a positive direction, such as doing freedom of work. The purpose of this research is to find out the ideology of women's equality and freedom in the novel $A l$-hubb fii zamani nafti. This research method uses a descriptive qualitative method that describes the date clearly. The data source is the novel Al-hubb fii zamani nafti. The data collection technique by reading, understanding, searching, and marking data. The research results contained in the novel Al-hubb fii zamani nafti describe the ideology of equality towards humans, tools, culture. And describes the freedom of women to work as sculptor, which is generally done by men.

Keyword: Equality, Women's Freedom, Posmodernism.

\section{Pendahuluan}

Dalam kehidupan manusia, Ideologi mempunyai peran penting dalam menambah keyakinan dan perjuangan kelompok untuk berpegang teguh kepada Ideologi itu sendiri. Bahkan Ideologi menjadi sumber inspirasi untuk kehidupan manusia dan dapat dijadikan sebagai pedoman hidup (Setiardja, 1993).

Ideologi tersendiri mempunyai arti sebagai suatu pengetahuan tentang ide-ide yang mencoba untuk melepaskan diri dari hal-hal metafisis, ideologi dapat dijadikan sebagai nilai-nilai dan berbagai kesepakatan yang harus ditaati dalam suatu kelompok sosial. Selain itu, Ideologi dapat menjadi motivasi kelompok sosial supaya dapat mendorong suatu tindakan (Nur Sayyid Santoso Kristeva, 2015). 
Masyarakat tentunya mempunyai tujuan yang hendak dicapai dan sebagai prosedur dalam menyelesaikan konflik yang terjadi di pada kelompok masyarakat tersebut (Winarno, 2012). Dalam konteks sastra, Ideologi sastra mempunyai tujuan untuk menempatkan manusia sebagai objek sekaligus subjek dalam rangka memaknai zaman. Adapun Ideologi yang berkaitan dengan kajian sastra merupakan gambaran secara keseluruhan yang mengandung arti ide atau gagasan, aspirasi-aspirasi, dan perasaan yang menghubungkan dan memperdebatkan anggota kelompok sosial dengan kelompok lainnya.

Ideologi kesetaraan adalah pemikiran yang sama antara laki-laki dan perempuan untuk berpegang teguh pada kehidupannya. Bahkan Ideologi Kesetaraan dalam feminisme berkaitan dengan kesetaraan gender antara laki-laki dan perempuan yang mempunyai kedudukan yang sama dalam hal apapun, salah satunya pekerjaan. Gender adalah konsep yang fokus pada peran dan tanggungjawab antara laki-laki dan perempuan yang dapat mengubah keadaan sosial budaya suatu masyarakat. Dengan adanya Kesetaraan Gender, laki-laki dan perempuan dapat memperoleh hak-hak yang sama dalam kegiatan politik, ekonomi, sosial, dan budaya (Ismawati, 1993).

Di negara Timur Tengah, salah satunya negara Mesir yang memiliki Ideologi Kesetaraan terendah (Maryam Jamilah, 2019). Adapun penyebab rendahnya kesetaraan di Mesir adalah selalu memposisikan perempuan diposisi kedua yang didukung dengan suatu sistem sosial yang menentang terhadap kesetaraan dan pihak laki-laki mendominasi dalam kekuasaan dalam segala aspek, baik kepemimpinan dalam politik, hak social bahkan otoritas moral (Knidri, 2009). Namun setelah sekian lama persepsi tersebut berkembang, kaum perempuan mulai muncul membicarakan tentang pelecehan seksual bahkan sampai dengan masalah politik dan memperjuangkan kebebasan dan hak-hak yang diinginkan terutama sejak.

Adapun kebebasan yang selalu muncul dalam kehidupan masyarakat diantaranya kebebasan positif dan kebebasan negatif. Kebebasan positif yang biasanya memiliki hak kuasa untuk mewujudkan potensi seseorang menjadi lebih baik. Sedangkan kebebasan negatif biasanya menyerupai tindakan seseorang yang bebas berdasarkan perbuatan atau keinginannya sendiri, tanpa adanya paksaan dan perintah dari orang lain (Berlin, 1969). Biasanya masyarakat yang ingin memiliki kebebasan adalah kaum perempuan, karena kaum perempuan selalu berada di posisi kedua. Dalam buku zaitunah subhan, perempuan artinya dihargai, sedangkan perempuan dalam feminisme artinya kontruksi sosial yang identitasnya ditetapkan melalui gambaran. Namun, kaum perempuan juga memiliki hak bebas untuk melakukan sesuatu sesuai keinginannya tanpa adanya paksaan dan perintah. Tetapi, jika laki-laki menyuruh perempuan untuk berbuat buruk, maka perempuan itu berhak untuk menolak, karena perempuan juga ingin memiliki kebebasan (Zaitunah Subhan, 2015).

Dalam kehidupan sehari-hari, kebebasan perempuan selalu terjadi masalah yang tak terduga. Padahal, laki-laki dan perempuan sama-sama makhluk hidup yang diciptakan untuk bahagia tanpa campur tangan orang lain. Kaum perempuan ingin memiliki kebebasan untuk melakukan sesuatu sesuai keinginannya. Hal tersebut sering terjadi di negara Mesir, kaum perempuan aktif untuk berpartisipasi dalam demontrasi untuk menuntut perubahan masyarakat. Masyarakat Mesir selalu menggunakan kekerasan untuk menghancurkan kaum perempuan, tetapi kaum perempuan Mesir tidak pantang menyerah, bahkan aktif dalam memperjuangkan hak-haknya dan berkontribusi untuk menggulingkan 
ketidakadilan. Ketidakadilan dan kebebasan yang diterima kaum perempuan yang terjadi di negara Mesir masih menjadi polemik, terdapat banyak penelitian yang membahas bagaimana ketidakadilan tersebut baik dari sisi politik, pendidikan dan yang lainnya. Namun belum ada yang melakukan penelitian mengenai kesetaraan dan kebebasan perempuan yang dilihat dari sisi sastra.

Oleh karena itu, peneliti membahas tentang ideologi kesetaraan dan kebebasan perempuan dalam novel Al-hubb fii zamani nafti yang menggunakan analisis kritik sastra feminis. Pertama, Ideologi Kesetaraan yang membahas tentang kesetaraan antara laki-laki dan perempuan dalam hal pendidikan, jabatan, pekerjaan, dan sebagainya. Kedua, Kebebasan Perempuan yang membahas tentang kebeba san untuk pergi cuti atau keluar rumah, perempuan itu bekerja di bagian arkeologi sebagai pemahat patung yang biasa dilakukan oleh laki-laki pada umumnya. Demi sebuah pekerjaan tersebut, perempuan itu pergi cuti tanpa memberitahu siapapun untuk mendapatkan patung-patung yang diinginkan.

Metode yang digunakan dalam kajian ini adalah metode deskriptif kualitatif dengan menggunakan pendekatan kritik sastra feminis. Biasanya penelitian metode deskriptif kualitatif menggunakan latar alamiah untuk menggambarkan fenomena dan melibatkan metode yang ada, dengan menggunakan pendekatan kritik sastra feminis, pendekatan kritik sastra feminis ini hanya berdasarkan pemikiran feminisme untuk memperoleh keinginan adanya keadilan dalam memandang eksistensi perempuan, baik dalam penulis maupun karya sastra, karena kritik sastra feminis hanya memfokuskan analisis terhadap penilaian perempuan, gambaran perempuan dalam karya sastra, dan hubungan antara lakilaki dan perempuan dalam kehidupan masyarakat (Wiyatmi, 2012). Akan tetapi, penelitian ini menggunakan pendekatan Kritik Sastra Feminis sebagai pembaca pada perempuan serta pemikiran perempuan bahwa perempuan itu sebagai Liya (Wiyatmi, 2012).

Dengan demikian, Penelitian ini mendeskripsikan novel Al-hubb fii zamani nafti berupa Ideologi Kesetaraan dan Kebebasan Perempuan menggunakan pendekatan metode Deskriptif Kualitatif dan pendekatan Kritik Sastra Feminis. Menggunakan metode Deskriptif Kualitatif dapat memecahkan masalah dalam menggambarkan suatu keadaan subjek atau objek penelitian, serta dapat mengungkapkan data atau fakta dengan memberikan deskripsi yang ada, juga menggunakan pendekatan Kritik Sastra Feminis hanya memfokuskan pada pembaca perempuan dan membaca perempuan sebagai Liyan. Oleh karena itu, menggunakan metode tersebut, peneliti akan mendeskripsikan objek yang diteliti berupa novel untuk mengungkapkan fakta-fakta yang terjadi melalui tulisan dalam novel.

\section{Pembahasan}

\subsection{Novel sebagai karya sastra}

Setiap masyarakat sudah pasti pernah mendengar yang namanya sastra, tetapi sastra harus dilihat dari perkembangannya, karena sastra mempunyai pengalaman tersendiri. Oleh karena itu, sastra dapat dibagi menjadi beberapa macam, diantaranya sastra lama dan sastra baru. Pertama, sastra lama sebagai sarana untuk penumpahan ide atau gagasan tentang kehidupan sosial yang menggunakan kata-kata indah dan terdiri dari tiga macam genre. Kedua, sastra baru sebagai sarana untuk penumpahan ide atau gagasan tentang apa saja yang menggunakan bahasa bebas dan keindah annya dilihat dari substansi ceritanya (Ahyar, 2019). Sastra juga bagian dari kebudayaan yang diwujudkan dalam bentuk tulisan 
untuk mengajar, memerintah, menasehati, mencela, mengkritik, dan membenarkan sesuatu yang menurutnya baik (Teeuw, 1984). Sastra adalah sebuah ciptaan yang diutarakan secara spontan, karena sastra bersifat otonom dan sastra tidak berkomunikasi. Sastra dapat menyajikan hal-hal yang tanpa kita sadari, seperti laki-laki dan perempuan, roh dan benda, dan sebagainya. Dilihat dari sisi seni, sastra mempunyai sisi kreativitas dan imajinasi yang didalamnya mencakup kualitas, kuantitas, dan dinamika makna, bahkan imajinasi itu sendiri didasarkan atas kenyataan yang dijadikan sebagai sarana estetis dalam memberikan keseimbangan dari segi rohani, jasmani, dan sastra dapat memerikan hiburan tersendiri (Ratna, 2005).

Sastra menjadi bagian dari segi kebudayaan dan segi kesenian. Selain menjadi bagian tersebut, sastra dapat menjadi pengalaman yaitu untuk menampug sebuah jawaban yang utuh dari jiwa manusia ketika kesadarannya bersentuhan dengan kenyataan atau realita. Disebut dengan jawaban yang utuh, karena kegiatannya berupa akal pikiran yang sangat tinggi dan kenyataan yang dapat menyentuh kesadaran manusia, baik kesadaran yang ada pada dirinya sendiri, atau kesadaran yang ada diluar dirinya. Dalam kejadian ini, sastra dilihat dari segi pengalaman, karena pengalaman itu sendiri diungkapkan melalui bahasa. Sastra sebagai pengalaman yang melakukan kegiatan seperti membaca karya sastra, mendengar karya sastra, menciptakan karya sastra, dan mengkritik karya sastra (Sumardjo, 1986). Adapun menurut Saryono, sastra bukanlah benda mati, melainkan benda hidup atau sosok yang hidup. Arti sosok hidup disini adalah perkembangan sastra yang berjalan bersama dengan yang lainnya, seperti ekonomi, politik, sosial dan budaya. Sastra dianggap mampu untuk menjadi pemandu kearah jalan yang benar, karena sastra yang baik akan dituliskan atau diungkapkan dengan kejujuran, kesungguhan, dan kearifan hati nurani (Saryono, 2009).

Karya sastra disebut sebagai media pengarang untuk mengungkapkan ide-ide hasil renungan tentang makna dan hakikat hidup yang dialami. Karena seorang pengarang menjadi salah satu anggota masyarakat yang kreatif dan mengungkapkan kata-kata di kehidupan sehari-hari kepada para penikmat sastra. Dapat dikatakan bahwa karya sastra mempunyai dua bagian besar, yaitu struktur luar dan struktur dalam. Struktur luar yang menjadi ekspresi dengan segala daya estetikanya yang dimanfaatkan oleh para sastrawan untuk mengungkapkan struktur dalam, dan struktur dalam yang terdiri dari gagasan tentang hakikat dengan segala kompleks dan variasinya. Adapun jenis-jenis karya sastra yang dapat dibedakan menjadi dua bagian, yaitu sastra imajinatif dan sastra non-imajinatif. Sastra imajinatif cenderung bersifat khayali atau berimajinasi dan bahasanya cenderung konotatif, sedangkan sastra non-imajinatif cenderung mengemukakan fakta dan bahasanya cenderung denotatif. Karya sastra imajinatif berupa prosa dan puisi. Prosa dibagi menjadi fiksi dan drama. Dalam fiksi berupa novel, cerpen, novelet, dan dalam drama berupa drama prosa, drama puisi. Kemudian puisi hanya terdiri dari puisi epik, lirik, dan dramatik. Sedangkan karya sastra non-imajinatif berupa esai, kritik, biografi, otobiografi, sejarah, memoar, catatan harian, dan surat-surat. (Yanti, 2015)

Novel bagian dari karya sastra yang berbentuk prosa dan memiliki unsur intrinsik, ekstrinsik. Sebuah novel, biasanya hanya menggambarkan atau menceritakan tentang kehidupan manusia untuk berinteraksi dengan lingkungan sekitar, bahkan pengarang berusaha untuk memberikan arahan kepada para pembaca untuk mengetahui pesan yang tersembunyi, seperti gambaran atau realita kehidupan melalui cerita yang terkandung dalam karya sastra berupa novel tersebut (Ahyar, 2019). Adapun dalam 
arti luas, novel adalah cerita berbentuk prosa dengan cangkupan yang luas, maksud dari cangkupan yang luas berarti cerita dengan alur yang kompleks, tema yang komplek, karakter yang banyak, latar tempat dan suasana yang beragam. Adapun dalam karya sastra, pasti terdapat struktur-struktur. Salah satunya dalam karya sastra berupa novel, yaitu abstrak dalam arti isi cerita ditemukan pada bagian awal cerita, orientasi dalam arti latar, waktu dan suasana, komplikasi dalam arti urutan kejadian yang dihubungkan oleh sebab akibat, evaluasi dalam arti konflik yang terjadi pada komplikasi terarah, resolusi dalam arti bagian novel yang memunculkan solusi atas konflik, koda dalam arti bagian akhir atau penutupan dalam cerita (Ahyar, 2019).

Terdapat unsur-unsur dalam novel, yaitu unsur intrinsik dan unsur ekstrinsik. Unsur intrinsik berupa tema, penokohan, alur atau plot, gaya bahasa, latar tempat, latar waktu, latar suasana, sudut pandang, amanat. Kemudian unsur ekstrinsik berupa sejarah atau biografi pengarang, situasi dan kondisi, nilai moral, sosial, budaya, estetika. Terdapat beberapa ciri-ciri novel, yaitu ciri-ciri umum, ciriciri novel angkatan 20-30an, ciri-ciri novel remaja. Pertama, ciri-ciri umum yang memiliki jumlah kata lebih dari 35.000, isi novel minimal 100 halaman, cerita lebih panjang dan diulang-ulang, novel ditulis dengan narasi dan di dukung oleh deskripsi dalam menggambarkan situasi yang ada didalamnya. Kedua, ciri-ciri novel angkatan 20-30an yang memiliki tema tentang adat, kawin paksa, berisi kritik terhadap adat, tokoh yang diceritakan sampai meninggal dunia, memiliki bahasa yang kaku dan statis, memiliki bahasa yang santun, kata-kata yang berlebihan. Ketiga, ciri-ciri novel remaja yang memiliki tema tentang persahabatan, percintaan, dan menggunakan bahasa sehari-hari (Ahyar, 2019).

\subsection{Ideologi Kesetaraan dan Kebebasan Perempuan}

Ideologi berasal dari bahasa latin yaitu idea dan logos. Idea artinya pemikiran dan logos artinya ilmu pengetahuan. Oleh karena itu, Ideologi dapat diartikan sebagai rumusan pikiran di berbagai subjek atau kelompok masyarakat yang dijadikan sebagai dasar untuk di realisasikan. Ideologi juga memiliki pandangan atau sistem nilai yang secara keseluruhan dipegang oleh masyarakat. Menurut Gramsci, Ideologi memiliki keabsahan yang bersifat psikologis, bahwa ideologi mengatur manusia untuk mendapat kesadaran akan kedudukan dan perjuangan mereka. Adapun ideologi yang terbagi menjadi tiga bagian, yaitu ideologi terbuka, ideologi tertutup, dan ideologi tersirat. Pertama, Idelogi terbuka yang bersifat inklusif, tidak totaliter, dan tidak dipakai untuk melegitimasi kekuasaan sekelompok orang. Kedua, ideologi tertutup yang berisi teori tentang realitas seluruhnya, bahkan ideologi tertutup ini tidak dapat dikembangkan berdasarkan pengalaman, salah satu cirinya adalah mengklaim atas kebenaran yang tidak diragukan lagi. Ketiga, ideologi tersirat yang sering ditemukan dalam keadaan masyarakat tradisional tentang hakekat realitas kehidupan manusia (Kristeva, 2010).

Dalam kumpulan buku tulisan pancasila sebagai ideologi, Mubyarto mendefinisikan ideologi sebagai sejumlah doktrin, kepercayaan, dan simbol kelompok masyarakat yang menjadi pegangan hidup untuk mencapai tujuannya. Menurut Karl Mark, ideologi disebut juga dengan seperangkat gagasan yang membentuk landasan teori ekonomi dan teori politik yang dipegang oleh seseorang atau sekelompok orang. Ramlan Surbakti mengatakan bahwa ideologi adalah suatu sistem nilai atau pandangan menyeluruh atau mendalam tentang tujuan yang harus dicapai oleh kalangan masyarakat dan tentang cara-cara yang dianggap baik untuk mencapai tujuannya. Bahkan ideologi dalam 
masyarakat mempunya dua fungsi, diantaranya sebagai tujuan atau cita-cita yang harus dicapai oleh suatu masyarakat dan sebagai pemersatu masyarakat dalam penyelesaian konflik yang terjadi di kalangan masyarakat (Winarno, 2012).

Kesetaraan adalah keseimbangan kondisi laki-laki dan perempuan untuk mendapat hak dan kewajiban secara adil, salah satunya dalam hal pekerjaan. Dalam Islam, kesetaraan manusia sudah ada pada zaman nabi sampai saat ini. Masalah gender terdapat dalam budaya kehidupan. Pada ajaran ketauhidan, Islam menjadi salah satu ajaran yang menjadi landasan nilai budaya dan norma sosial dalam menyelesaikan masalah-masalah. Adapun masalah gender, gender adalah perbedaan antara laki-laki dan perempuan yang dibangun secara sosial dengan peran, perilaku, dan sifat seseorang antara laki-laki dan perempuan yang dapat dipertukarkan. Bahkan sering kali kata gender diartikan sebagai perempuan dan setiap kegiatan atau aktivitas yang berhubungan dengan gender selalu dikaitkan dengan perempuan, padahal gender berbeda dengan perempuan. Oleh karena itu, kesetaraan gender berlaku untuk laki-laki dan perempuan (Azisah, 2016).

Gender berasal dari hasil kontruksi budaya yang diciptakan oleh manusia, seperti sifatnya yang berubah-ubah dan dapat dialihkan pertukaran dalam waktu, tempat, budaya setempat dari satu jenis kelamin dan ke jenis kelamin lainnya. Adapun sifat yang melekat pada laki-laki dan perempuan secara sosial maupun kultural bagian dari gender itu sendiri. Konsep gender yang lahir untuk merekontruksi hubungan laki-laki dan perempuan secara universal untuk membuka peluang yang sama dalam hal kehidupan tanpa dipengaruhi oleh gender. Dalam stereotip gender berhubungan dengan suatu ideologi yang melatarbelakangi pola pikir manusia untuk membuat aturan main dalam kehidupan masyarakat. Teori gender yang selalu diperdebatkan adalah teori nature dan teori nurture, kedua teori ini memperdebatkan masalah psikologis laki-laki dan perempuan. Teori nature menganggap perbedaan laki-laki dan perempuan yang disebabkan oleh perbedaan psikologisnya, sedangkan teori nurture menganggap perbedaan laki-laki dan perempuan yang disebabkan oleh proses belajar manusia dilingkungannya (Murniah, 2004).

Dalam hal apapun, laki-laki dan perempuan setara. Terutama dalam mengakses kebutuhan publik, seperti pendidikan, kesehatan, dan pekerjaan diluar sektor domestik. Kesetaraan gender menjadi penting karena memiliki beberapa tujuan. Pertama, pemerintah dapat bekerja lebih efisien dan efektif terhadap laki-laki maupun perempuan. Kedua, kebijakan pelayanan publik dan program undangundang yang adil bagi laki-laki maupun perempuan. Ketiga, pengutamaan gender menjadi upaya untuk menegakkan hak-hak laki-laki maupun perempuan atas kesempatan yang sama. Keempat, mengantarkan pada pencapaian kesetaraan gender untuk meningkatkan akuntabilitas pemerintah terhadap rakyatnya. Kelima, keberhasilan dalam memperkuat kehidupan sosial, politik, ekonomi, budaya suatu bangsa. Terdapat bentuk respon dalam kesetaraan gender yang berkembang di Indonesia bisa beragam dalam negosiasi. Perempuan yang berlatar belakang ekonomi rendah atau tinggi, mereka mempunyai daya tawar masing-masing, sehingga negosiasi akan berbeda-beda. Dilihat dari persepsi kepantasan, nilai kesetaraan gender akan menjadi kunci meskipun posisi sosial di Indonesia masih jauh dari sempurna dalam konsep kesetaraan gender (Djoharwinarlien, 2012).

Pada dasarnya, kebebasan adalah melakukan segala sesuatu tanpa adanya paksaan dari siapapun. Bahkan kebebasan dibagi menjadi dua konsep , yaitu kebebasan kearah yang positif dan kebebasan 
kearah yang negatif. Pertama, kebebasan positif biasanya kebebasan yang tidak mengalami kekerasan dan mempunyai cara untuk mewujudkan kehidupannya. Kedua, kebebasan negatif biasanya kebebasan yang tidak mengalami kekerasan sehingga dapat menjalani hidup sesuai keinginannya sendiri. Oleh karena itu, supaya mendapat kebebasan positif, perlu diperhatikan keputusan atau tindakan yang memenuhi standar tertentu dalam kehidupan dunia nyata (El-Harmouzi, 2016).

Pada masa pra Islam, perempuan dianggap sebagai mahkluk yang tidak berharga, karena keberadaan perempuan sangat menganggu, sering membuat masalah, hak-haknya dirampas, tubuhnya diperjual belikan. Perempuan adalah fenomena dalam feminisme, karena perempuan hidup dan tanggung jawab sosial yang terkurung oleh budaya patriarki, dengan kondisi ini, perempuan menjalani hidup dan berkembang sebagai anggota kultur umum laki-laki dan anggota kultur perempuan. Adapun para perempuan dunia beranggapan bahwa perempuan itu masih berada di posisi terendah, karena proses sejarah yang membuat seorang perempuan dianggap pembantu oleh laki-laki. Bahkan pengaruh dari ideologi gender menyatakan bahwa perempuan diperlakukan sebagai objek pola konsumsi, sebagai buruh murah, sebagai pekerja migran, sebagai mekanisme komodisi seksual, sebagai turisme, sebagai perdagangan seksual, sebagai kerusakan lingkungan (Murniah, 2004).

\subsection{Kritik Sastra Feminis}

Kritik Sastra Feminis disebut dengan pengkritik atau pembaca perempuan yang memandang sastra sebagai kesadaran khusus bahwa terdapat jenis kelamin yang berhubungan dengan budaya, sastra, dan kehidupan. Jenis kelamin inilah yang membedakan semuanya, seperti perbedaan pada pengarang, perbedaan pada pembaca, perbedaan pada karya sastra, dan lain-lain. Dalam kritik sastra feminis menyatakan bahwa sebagai seorang perempuan dapat membaca sebagai perempuan. Kritik sastra feminis sangat berbeda dari kritik yang lain, kritik ini diperlukan adanya wawasan yang luas dalam bacaan tentang perempuan. Namun pada kenyataannya, kritik sastra feminis ini tidak mencari metodologi, melainkan dapat menjadi pluralis dalam teori juga praktinya dalam menggunakan kebebasan metodologi dan pendekatan yang dapat membantu (Sugihastuti, 2000).

Tugas kritik sastra feminis adalah mencari perbedaan dan pengalaman yang menggunakan imajinasi dalam merepresentasikan perempuan. Bahkan kritik sastra feminis harus mencari su atu kenyataan yang ada dibalik karya sastra fiksi. Dalam menerapkan pendekatan kritik sastra feminis, ada baiknya mengikuti pandangan dari Barret, yaitu mampu membedakan material sastra yang ditulis dengan menarik oleh laki-laki maupun perempuan, bahkan dalam prinsipnya, laki-laki dan perempuan harus mampu membedakan ideologi, mengetahui kodrat fiksional teks sastra yang mampu melukiskan budaya laki-laki dan perempuan, karena budaya laki-laki dan perempuan memiliki suatu perbedaan yang harus dijelaskan melalui analisis gender (Pradopo, 1995).

Adapun Teori yang berkaitan dengan analisis yang dikaji, yaitu teori Posmodernisme. Teori Posmodernisme ini terbagi menjadi dua bagian, yaitu: Pertama, Teori Posmodernisme Kuat. Kedua, Teori Posmodernisme Lemah. Posmodernisme kuat ini lebih mendukung kearah perbedaan yang tidak terbatas. Oleh karena itu, Posmodernisme kuat ini menunjukkan kecenderungan kearah normalisme yang menolak gagasan bahwa kenyataan dalam dunia nyata benar-benar sesuai dengan konsep, konsep yang dapat membentuk dan menciptakan suatu kenyataan. Bahkan Posmodernisme ini lebih menyukai 
penampilan dan retorika dibanding dengan kebenaran intrinsik yang universal, serta menolak segala sesuatu tentang pengetahuan yang membuuat rujukan eksplisit pada narasi besar. Disisi lain, kritik ini mengungkapkan eksklusivitas gender berupa modernitas progresif. Dalam istilah posmodernisme, posmodernisme kuat ini tidak dapat membuat pernyataan yang tidak bersyarat, seperti pernyataan melakukan penindasan terhadap perempuan adalah sebuah kesalahan, bahkan para feminis menyatakan bahwa istilah perempuan hanyalah penanda yang tidak memiliki isi, hanya saja sebuah kata-kata dalam permainan bahasa tertentu yang secara kebetulan dipakai. Menurut Rorty, yang membuat posmodernisme ini kuat adalah dengan kepercayaan, kepercayaan yang dimaksud adalah kepercayaan masyarakat yang dapat diubah tanpa melakukan kekerasan melalui kata-kata (Jones, 2009).

Menurut Lyotard, Posmodernisme kuat ini memiliki kominten para pemikir pasca-pencerahan menciptakan keadilan sosial, pencarian pengetahuan yang objektif sebagai dasar kemajuan sosial. Namun, Lyotard ini menyatakan bahwa tidak mungkin ada dasar bagi kebenaran, karena ilmu dan filsafat bagian dari wacana yang kebenarannya masuk akal dalam kerangka organisasi internal. Dalam dunia posmodern, pengetahuan yang biasa-biasa saja telah terpecah belah menjadi permainan bahasa heterogen dengan aturan internalnya sendiri. Karena sudah tidak mungkin lagi adanya kepercayaan, seperti alam, sejarah, ruh, dan rasio murni yang dapat mendasari kebenaran. Bagi feminis, turunan dari hal ini adalah gender, seperti kelas, ras, etnisitas, bahkan tidak dianggap lagi sebagai kategori yang memiliki hakikat dan tidak dapat digunakan untuk menjelaskan praktik-praktik masyarakat secara keseluruhan. Dengan demikian, dilihat dari segi logika pandangan Lyotard bahwa kesetiaan terus menerus pada metanarasi gender yang membuat para teoritis feminis tidak dapat melihat watak etnosentris dan heterogenis yang menindas, bahkan bersembunyi dibalik semua kebenaran esensialis mengenai sifat dasar pengalaman perempuan atau feminim. Terlebih lagi, pandangan Lyotard yang mengaplikasikan untuk merumuskan struktur historis sebagai cara dalam penindasan dan cara sebaliknya. Tetapi, pemikiran Lyotard, kita meragukan keterbukaan karena tesisnya mengandung unsur yang tersembunyi. Posmodernisme yang sekarang menawarkan dunia sepenuhnya diestetiskan (Jones, 2009).

Adapun Posmodernisme lemah yang dapat menerima kebutuhan manusia untuk meyakini narasinarasi besar, meskipun penganjurnya menolak narasi besar dan berisi keras untuk mengemukakan bahwa pengetahuan akan tertanam dalam budaya tertentu. Pemahaman pengetahuan ini berasal dari adat kebiasaan dan segala praktik dalam budaya. Posmodernisme lemah ini membuat keinginan untuk mencapai suatu objek atau dorongan yang harrus dijaga dan diikutsertakan untuk turun ke bumi secara kultural. Dengan cara ini, posmodernisme lemah dapat melawan godaan posmodernisme kuat dengan memandang dari segala tempat, tidak menumbuh, tidak memiliki pusat yang mendukungnya. Titik dimulainya posmodernisme lemah ini oleh Martin Heidegger dan tradisi teori hermeneutik. Menurutnya modernitas ditandai dengan ketidaksetujuan dan pengingkaran pada ada dunia ini, lebih jelasnya bahwa kita ada di dunia ini harus memperlihatkan subjek yang terbuka tanpa dunis tidak pernah terjadi. Meskipun tidak pernah mencapai pengetahuan yang penuh, tetapi kita dapat mengubahnya dengan pengalaman pada kebenaran yang terlihat kontradiktif dengan diri kita sendiri. Penjelasan menurut Gadamer mengenai pengetahuan "menumbuh" akan berguna untuk menyingkirkan pemisahan gender 
antara pikiran dan tubuh. Dan menyarankan semua pemahaman manusia yang berakar untuk mewujudkan hubungan dan tradisi budaya yang mendalam tidak dapat memisahkan rasio dan adat (Jones, 2009).

\subsection{Kesetaraan dan Kebebasan Perempuan dalam novel Al-Hubb fii Zamani Nafti}

Adapun karya sastra yang dikaji oleh peneliti berupa novel yang berjudul Al-hubb fii zamani nafti karya Nawal El-Saadawi yang diterbitkan pada tahun 1993 di Kairo dan penerbitnya adalah Maktabah Al-Badbulii. Sedangkan novel terjemahannya yang berjudul Love in the kingdom of oil yang diterbitkan pada tahun 2012 di Jakarta dan penerbitnya adalah Yayasan Pustaka Obor Indonesia. Nawal El-Saadawi merupakan tokoh perempuan yang berasal dari Mesir, beliau juga terkenal sebagai novelis dan penulis pejuang hak-hak perempuan. Bahkan beliau menerbitkan buku pertamanya yang berjudul women and sex. Setelah itu, menerbitkan buku-buku lainnya tentang status, psikologi, dan seksualitas perempuan. Kemudian novel yang penulis kaji karya Nawal El-Saadawi menceritakan tentang seorang perempuan berasal dari Timur Tengah menghilang tanpa jejak yang bekerja di bagian arkeologi sebagai pemahat patung-patung dewa. Pekerjaan yang perempuan lakukan adalah pekerjaan yang berat, yaitu mencari patung-patung dewa dengan cara menggali tanah menggunakan pahat.

Penelitian ini bertujuan untuk mendeskripsikan Ideologi Kesetaraan dan Kebebasan Perempuan dalam novel Al-hubb fii zamani nafti karya Nawal El-Saadawi. Adapun yang dianalisis oleh penulis. Pertama, ideologi kesetaraan terhadap manusia yaitu antara laki-laki dan perempuan yang memiliki hak atas apa yang mereka inginkan. Kedua, kebebasan perempuan yang memiliki kebebasan untuk pergi cuti atau keluar rumah, karena perempuan itu mempunyai alasan untuk cuti, yaitu demi pekerjaan sebagai pemahat patung-patung dan ingin menemukan patung dewi yang selama ini telah hilang ditelan bumi. Ketiga, kebebasan perempuan yang bekerja di bagian arkeologi sebagai pemahat patung. Pekerjaan ini sering dilakukan oleh laki-laki, tetapi perempuan itu mampu melakukan pekerjaan tersebut. Karena ketika perempuan itu masih kecil, perempuan itu melihat kerabatnya yang melakukan pekerjaan berat ini seperti memahat patung, jadi perempuan tersebut memiliki keinginan untuk meneruskan pekerjaan memahat patung yang biasa dilakukan oleh laki-laki.

Adapun kutipan yang menunjukkan Ideologi Kesetaraan dan Kebebasan Perempuan, diantaranya: 1. Ideologi Kesetaraan

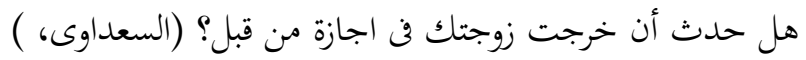

“Apakah istri anda pernah meninggalkan rumah?” (El-Saadawi, 2012).

Pada kutipan di atas, dijelaskan bahwa seorang istri juga mempunyai hak untuk meninggalkan rumah. Meninggalkan rumah bukan berarti kabur dari rumah, bisa saja seorang Istri meninggalkan rumah untuk mencari sesuatu yang hilang. Perempuan itu mempunyai tanggung jawab terhadap pekerjaannya yaitu sebagai peneliti untuk mencari patung-patung dewa, sedangkan alat untuk mencari patung patung adalah pahat. Pada kutipan dalam novel tersebut, seorang Istri selalu meminta izin untuk keluar rumah. Pada dasarnya seorang laki-laki juga pasti pernah meninggalkan rumah. Jika sudah berkeluarga, seorang laki-laki atau suami mempunyai tanggung jawab besar untuk menafkahi keluarganya, sedangkan seorang perempuan atau istri hanya menuruti perintah suami. Tetapi 
perempuan yang terdapat dalam novel, perempuan itu mempunyai tanggung jawab terhadap pekerjaannya yang bekerja di bagian arkeologi sebagai peneliti untuk mencari patung-patung dewa. Perempuan itu cuti karena mempunyai alasan yang jelas yaitu bertanggung jawab terhadap pekerjaan Oleh karena itu seorang perempuan atau istri dan seorang laki-laki atau suami mempunyai ideologi yang setara terhadap kegiatan yang dilakukan sehari-hari dan tanggung jawab yang mereka harus laksanakan, karena tanggung jawab adalah beban yang berat.

2. Kebebasan Perempuan

$$
\begin{aligned}
& \text { رمقها رئيس القسم بعيون متسعة .علقت الحقيبة فوق كتفها بلا صوت ـ شدت الباب بحذر وخرجت ـ صوت الريح } \\
& \text { يعوى كصوت الذئاب الجائعة ـ قدماها تغوصان مع كل خطوة ـ لاتعرف السائل من اليابس ـ هذا القسم لا يقبل } \\
& \text { إلا الذكور ، فالعمل غير ملائم .. أعنى حفر الأرض.. ( السعداوى، 28-29). }
\end{aligned}
$$

"Kepala departemen memandangnya dengan mata terbelalak, bagian ini hanya menerima lakilaki. Pekerjaan yang kami lakukan, maksudku, menggali tanah, tidak cocok untukmu” (ElSaadawi, 2012).

Pada kutipan di atas, perempuan itu melihat lowongan pekerjaan sebagai peneliti di bagian arkeologi. Kemudian perempuan itu mencoba untuk mendaftarkan diri dan mengisi formulir, ketika kepala departemen itu melihat formulir yang diisi oleh perempuan itu, kepala departemen itu memandang dengan mata terbelalak. Karena pekerjaan yang akan dilakukan hanya untuk laki-laki saja yaitu menggali tanah, tetapi sebelum mendaftar sebagai peneliti di bagian arkeologi, perempuan itu sudah tahu pekerjaan seperti apa yang akan dilakukannya. Perempuan itu bekerja sebagai peneliti yaitu mencari patungpatung dan ingin seperti bibinya. Pada zaman dahulu, kerabatnya bekerja sebagai pemahat patung. Perempuan itu ingin membuktikan kepada semua orang bahwa seorang perempuan juga bisa melakukan pekerjaan menggali tanah. Namun, tetap saja kepala departemen mengungkapkan bahwa pekerjaan ini hanya dilakukan oleh laki-laki. Sedangkan perempuan itu tetap bersikeras ingin mendaftar menjadi peneliti yaitu menggali tanah, karena perempuan itu sering melihat kerabat dan ibunya menggali tanah seperti menanam benih. Menggali tanah yang dimaksud kepala departemen itu bukan seperti bercocok tanam, melainkan menggali tanah untuk mencari patung-patung dewa. Padahal perempuan itu sudah tahu tentang patung-patung sejak dahulu kala. Oleh karena itu, perempuan itu mempunyai kebebasan untuk mendaftar sebagai pemahat patung atau menggali tanah menggunakan pahat untuk meneruskan jejak kerabatnya yang bekerja sebagai pemahat patung juga.

\section{Kesimpulan}

Setelah menganalisis novel Al-hubb fii zamani nafti karya Nawal El-Saadawi yang menggunakan analisis kritik sastra feminis. Penelitian ini dapat disimpulkan, diantaranya: Pertama, bentuk Ideologi kesetaraan terhadap manusia, benda dan budaya, seperti perempuan dan laki-laki sama-sama memiliki hak untuk pergi sesuai dengan keinginannya sendiri selama memberikan arti kebermanfaatan dan positif, aspek benda yaitu perempuan memiliki kebebasan dalam menggunakan alat dlama melakukan sesuatu dan pada aspek budaya adalah terdapat para perempuan yang melihat seorang perempuan muda yang membawa pahat dalam tasnya, bahkan tidak memakai cadar. Para perempuan itu terus memperhatikan seorang perempuan muda yang terlihat asing tersebut dan menghampirinya untuk 
menanyakan kenapa tidak memakai cadar, seorang perempuan itu hanya terdiam saja, dan para perempuan itu memahaminya bahwa di kampung halamannya tidak memakai cadar, karena para perempuan itu belum pernah melihat seorang perempuan muda tersebut. Kedua, bentuk kebebasan perempuan yang memiliki kebebasan terhadap pekerjaannya, seorang perempuan yang bekerja di bagian Arkeologi sebagai pemahat patung, pekerjaan yang biasa dilakukan oleh laki-laki, karena pekerjaannya yang berat seperti mencari patung-patung dewa dengan cara menggali tanah menggunakan pahat. Bahkan, perempuan itu mampu melakukan pekerjaan tersebut.

\section{Referensi}

Ahyar, J. (2019). Apa itu sastra: Jenis-jenis karya sastra dan bagaimanakah cara menulis dan mengapresiasi sastra. Sleman: Deepublish.

Azisah, S. (2016). Buku Saku Kontekstualitas Gender Islam dan Budaya. Makassar: Global Affairs Canada. Berlin, I. (1969). Empat Esai Kebebasan. Jakarta: LP3ES dan Freedom Institute.

Djoharwinarlien, S. (2012). Dilema kesetaraan gender refleksi dan responsi praktis. Yogyakarta: PolGov.

El-Harmouzi, L. W. \& N. (2016). Islam dan Kebebasan:argumen islam untuk masyarakat bebas. Suara Kebebasan.

El-Saadawi, N. (2012). Love in the kingdom of oil. Jakarta: Yayasan Pustaka Obor Indonesia.

Ismawati, E. (1993). Ilmu Sosial Budaya Dasar. Yogyakarta: Ombak.

Jones, S. J. \& J. (2009). Pengantar Teori-teori feminism kontemporer. Yogyakarta \& Bandung: Jalasutra.

Knidri, M. (2009). Women in Arab Societies the cas of Morocco. Maroko: Cadi Ayyad University Morocco.

Kristeva, N. S. S. (2010). Sejarah Ideologi Dunia:Kapitalisme, sosialisme, komunisme, fasisme, anarkisme, anarkisme dan marxisme, konservatisme. Yogyakarta: Eye the Revolution Press y.

Maryam Jamilah. (2019). Ketidaksetaraan Gender Perempuan Mesir di Bidang Politik Pasca Arab Spring 2011. BUANA GENDER : Jurnal Studi Gender Dan Anak, 2(2), 149-163.

Murniah, A. N. P. (2004). Getar Gender. Magelang: Yayasan Indonesia Tera.

Nur Sayyid Santoso Kristeva. (2015). Sejarah Ideologi Dunia. Lentera Kreasindo.

Pradopo. (1995). Beberapa Teori Sastra, Metode, dan Penggunaannya. Yogyakarta: Pustaka Pelajar.

Ratna, N. K. (2005). Sastra dan Cultural Studies Representasi Fiksi dan Fakta. Yogyakarta: Pustaka Pelajar. Saryono. (2009). Dasar Apresiasi Sastra. Yogyakarta: Elmatera Publishing.

Setiardja, G. (1993). Hak-hak Asasi Manusia berdasarkan Ideologi Pancasila. Yogyakarta: Kanisius.

Sugihastuti. (2000). Wanita dimata Wanita perspektif sajak-sajak Toety Herarty. Bandung: Nuansa.

Sumardjo, J. (1986). Apresiasi Kesusastraan. Jakarta: Gramedia.

Teeuw, A. (1984). Sastra dan Ilmu Sastra, Pengantar Teori Sastra. Jakarta: Jakarta Pustaka Jaya.

Winarno. (2012). Kebijakan Publik: Teori, Proses, dan Studi kasus Budi Winarno. Yogyakarta: CAPS.

Wiyatmi. (2012). Kritik Sastra Feminis Teori dan Aplikasinya dalam Sastra Indonesia. Yogyakarta: Ombak.

Yanti, C. S. (2015). Religiositas Islam Dalam Ratu Yang Bersujud Karya Amrizal Mochamad Mahdavi. Jurnal Humanika, 3(15), 1-15.

Zaitunah Subhan. (2015). Al-Qur'an \& Perempuan Menuju Kesetaraan Gender dalam Penafsiran. Jakarta: Prenada Media Group. 